\author{
돌발성 난청을 보인 소뇌동맥 경색증 1 례 \\ 한양대학교 의과대학 이비인후과학교실 \\ 이승환 · 정승원 · 박철원 · 박혜경 · 김기태
}

\title{
A Case of Cerebellar Infarction Presenting Sudden Hearing Loss
}

\author{
Seung Hwan Lee, MD, Seung Won Jeong, MD, Chul Won Park, MD, \\ Hye Kyung Park, MD and Ki Tae Kim, MD \\ Department of Otolaryngology, College of Medicine, Hanyang University, Seoul, Korea
}

\section{- ABSTRACT -}

Sudden hearing loss is defined as an abrupt onset of sensorineural hearing disturbance which develops over a period of several hours or a few days without definite cause. Viral and vascular origin were suggested most causative problems developing sudden hearing loss. We report one case , complains sudden hearing disturbance with dizziness and then facial nerve weakness, tongue bite was developed subsequently. In brain MRI, anterior inferior cerebellar artery infarction was noted. After treatment of infarction, cerebellar function was improved but hearing loss was not recovered. We must remind the possibility that hearing loss was a leading symptom in cerebellar infarction. ( $\mathbf{J}$ Clinical Otolaryngol 2001;12:80-82)

KEY WORDS : Sudden hearing loss · Cerebellar infarction.

\section{서 론}

돌발성난청은 수 시간에서 수 일내에 일측 또는 양측 으로 나타나는 원인불명의 감각신경성 난청을 보이며 이명과 현기증을 동반하기도하는 질환으로 조기에 정확 한 진단과 치료가 시행되지 않으면 영구적인 후유증을 남기는 이과적으로는 응급질환이다. ${ }^{1-4)}$ 원인에 정설은 없지만 바이러스성, 혈관성이 가장 많은 요인으로 알려 져 있으며 그 외에는 면역학적인 결함, 외상이나 감염,

논문접수일 : 2001년 1월 22일

심사완료일 : 2001년 3월 31일

교신저자 : 이승환, 471- 020 경기도 구리시 교문동 249- 1

한양대학교 의과대학 이비인후과학교실

전화 : (031) 560- 2360· 전송 : (031) 566- 4884

E- mail : shlee@ hmc.hany ang.ac.kr
중추 또는 말초신경변화, 종양질환과 이독성약물에 의 한 것 등 여러 가지가 있다. ${ }^{2)}$ 이 중 혈관성의 원인에는 감각기에 혈액공급을 하는 미세소혈관의 침전물, 혈관수 축 및 경련과 혈관염 등이 그 원인이 되며 또한 보다 상 위혈관의 병변으로 인하여 전신적인 뇌기능 장애와 더 불어 발생할 수도 있다. ${ }^{4)}$ 저자들은 돌발성 난청을 보인 소뇌동맥 경색증 1 례를 경험하였기에 보고하는 바이다.

\section{증 례}

64세 남자환자로 5일전부터 시작된 좌측의 급격한 청 력감퇴를 주소로 본원 이비인후과 외래에 내원하였다. 동반증상으로는 1일전부터 이명을 동반한 어지러움증 과 복시를 호소하였다. 과거력상 당뇨진단을 받은 적이 있으나 특이한 치료는 하지 않았으며 혈압은 정상범위 


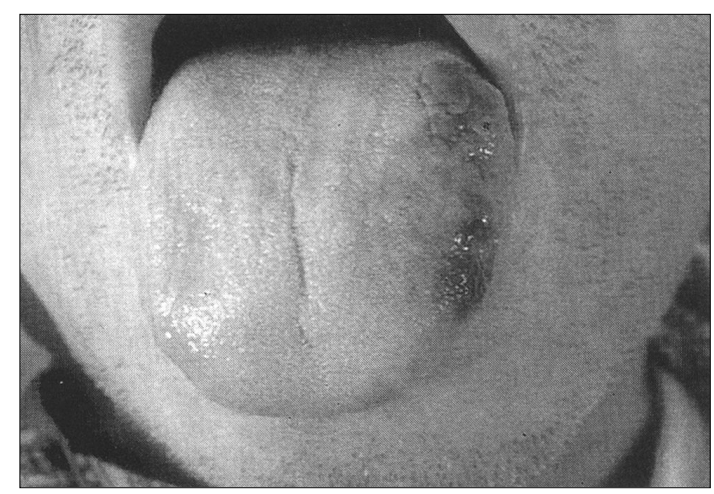

Fig. 1. Photograph of patient's bitten tongue due to decreased sensation of pain regardless of patient's will.

였다. 가족력상 특이 소견은 없었다. 환자는 고막은 정 상이었고 사지운동은 감퇴되어 있었으나 뚜렷한 병변보 다는 만성적인 근력약화로 생각되었고 감각기능의 이 상소견은 발견되지 않았다. 외래에서 시행한 청력검사상 에서 우측은 정상범위였으나 좌측은 전농소견을 보였다. 웨버검사 Weber test) 상에서 우측 편위 소견을 보였 다. 좌측에 발생한 돌발성난청으로 사료되어 입원치료 를 시작하였다. 환자는 당일 저녁에 시행한 전정기능검 사상에서 방향우위성 안진이 발견되었으며 양측 모두 에서 각 방향으로 수평 편위되는 안진 소견을 보였다. 혈액검사상에서는 특이한 소견 없었으며 생화학검사상 글루코스가 $352 \mathrm{mg} / \mathrm{dl}(60$ 110 mg/dl), 소변검사상에 서 글루코스 양성 반응으로 당뇨에 합당한 결과 확인되 었다. 환자 입원 2 일째에 갑자기 좌측 혀의 감각 이상을 호소하며 혀를 깨무는 일이 일어났다 (Fig. 1). HouseBrackmann grade II에 해당하는 좌측 안면 신경 마비 가 발견되었고 목젓의 우측편위가 관찰되었다. 청력 검 사상 변동 없었으며 상하지의 운동이나 감각은 큰 이상 이 없었다. 입원 3 일째 좌측 안면 신경 마비가 HouseBrackmann grade III 정도로 악화되었으며 이때부터 좌측으로의 실조성 보행이 발견되었다.

이날 실시한 뇌 자기공명영상에서 T1 강조영상중 뇌 간 및 제 7,8 뇌신경의 기시부에서 비교적 높은 신호강도 가 관찰되었으며 이 부위의 조영시 약간 조영증강되는 소 견을 보였다(Fig. 2). T 2 강조영상에서는 같은 부위에서 T1 강조영상에 비하여 높은 신호강도를 보였다 Fig. 3).

이상의 소견에서 좌측 전하소뇌영역의 경색으로 생각

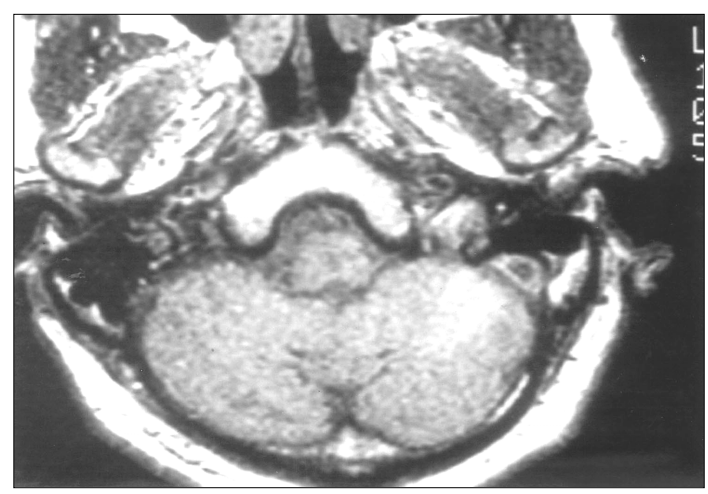

Fig. 2. Tl weighted axial image shows relatively round increased high signal intensity lesion in the left anterior inferior cerebellar artery ( AICA) region.

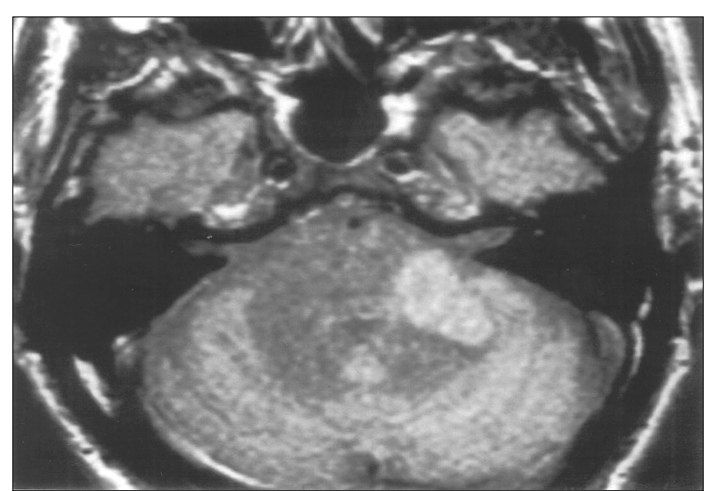

Fig. 3. T2 weighted image shows increased high signal intensity lesion in the left anteior inferior cerebellar artery territory compared with $\mathrm{Tl}$ weighted image.

되어 신경과로 전과되었고 혈전용해제와 혈소판제제 투 여하면서 물리재활치료를 병행하였다. 환자는 이후 신경 과에서 치료받았으며 입원 31일째에 신경학적인 증상 의 호전을 보이며 퇴원하였다.

퇴원 3주후 외래 방문시 안면신경마비는 House- $\mathrm{Br}$ ackmann grade II로 향상되었으며 안면 감각 및 혀의 감각이상도 향상되었다. 전신적인 쇠약은 남아있었으나 실조성 보행은 많이 호전되었고 어지러움이나 안진도 나타나지 않았다. 하지만 청력검사상에서는 여전히 좌 측은 전농소견을 보였다. 이후로 약 한달내지 두달에 한번 본원 신경과 및 이비인후과 외래 추적관찰 중이다.

\section{고 찰}

기저동맥에서 분지되는 전하소뇌동맥는 비교적 작은 
혈관으로 뇌교의 하부와 소뇌 연수의 상부일부와 내이 에 혈액을 공급하는 혈관이다. ${ }^{78)}$ 크게 4 가지 임상양상 이 이 혈관의 경색으로 인하여 나타난다고 언급되어있는 데(6)7) 첫째 $\mathrm{Adams}^{11)}$ 가 1943년에 보고한 바로는 주로 어지러움, 이명, 구토, 구음장애가 있으며 여기에 동측의 안면신경마비, 청력장애, 삼차 신경 마비, 운동거리조정 이상, 반대측 상하지의 체온감각, 통증인지의 감퇴가 온 다. 전하소뇌동맥의 공급 영역이 확장되어있는 경우에는 동측으로의 안구운동마비와 연하곤란이 나타날 수 있다. 두 번째로는 사지마비를 동반한 혼수상태가 발생 할 수 있다. 세 번째로는 전정미로염처럼 나타나는 어지러움만 을 주증상으로 나타날 수 있으며 전하소뇌동맥이 일부만 막히는 경우에서 나타난다. 마지막으로 소뇌 병변에 국한 된 증상만을 나타내는 경우가 있다. 이러한 전하소뇌동맥 경색의 원인은 혈전, 미세색전 등으로 인해 생긴다. 대개 는 기저질환(동맥경화, 심장질환, 고혈압, 당뇨, 고지혈 증) 이 있는 사람들에게서 많이 발생하는 것으로 되어있 다. 전형적으로는 상위 혈관인 기저동맥의 폐색으로 인하 여 이것이 전하소뇌동맥으로의 확장으로 인해 생긴다고 한다. ${ }^{8-10)}$

통상적으로는 이러한 경색이 생긴 경우는 한가지 증 상만 나타나기는 드물며 여러 가지 앞에 언급한 증상 특 히 중추증상이 먼저 나타나는 경우가 대부분이다. 그리 하여 이러한 환자를 이비인후과의사가 먼저 보기는 흔 하지 않다.

하지만 Deschauer 등히이 난청이 전하소뇌동맥경색 증의 초기증상으로 보였던 2 명의 환자를 보고하였고 따라서 돌발성 난청를 보이는 모든 환자에게서 이러한 중추적인 질환을 감별하기 위하여 뇌간(Brain stem)에 대한 검진을 주장하였다.

또한 Kido등기는 돌발성 난청과 어지러움을 주증상으 로 하여 내원한 소뇌동맥경색증 환자 1례를 보고하였다. 이렇듯 원인이 밝혀진 돌발성 난청에 대한 치료는 명백 하며 혈전용해제, 항혈소판제제, 헤파린(Heparin) 투여 등을 시행하며 원인이 되는 기저질환에 대한 철저한 검 사가 중요하다. 상기 환자에서도 동일한 치료를 하여 신 경학적인 증상은 많이 개선되었으나 청력은 비가역적인 상태로 회복이 되지 않았다.

\section{결 론}

돌발성 난청은 난해한 질환이며 특히 혈관 질환에 의 한 경우 신경학적인 이상이 나타나면서 심하면 생명에 까지 영향을 줄 수 있으므로 돌발성 난청 환자를 접할 때 항상 전신상태를 같이 파악하면서 기본적인 신경학 적 검사를 하여야 할것이며 이러한 경우 감별에 도움을 주기 위하여 영상학적인 검사와 전정기능검사 등이 필 요할 것으로 사료된다.

저자들은 최근에 어지러움이 있으면서 돌발성 난청 을 초기 증상으로 내원한 소뇌동맥경색증 1례를 경험 하였기에 이에 보고하는 바이다.

중심 단어 : 돌발성 난청. 소뇌경색.

\section{REFERENCES}

1) Deschauer M, Georgiadis D, Lindner A. Hearing loss as the leading symptom in anterior inferior cerebellar artery infarction. Fortschr Neurol Psychiatr 1998 Mar;66(3): 109-12.

2) Yim KC, Park KY, Lee KI, Kim JY, Chun KD. Clinical analysis of sudden hearing loss. Korean J otolaryngol $1995 ; 28(6): 834-41$.

3) Kim SM, Park GJ, Lee WY, Kim JA. Clinical assessment of sudden hearing loss. Korean J otolaryngol 1994;37(2): 231-9.

4) Kwon TH, Kim BS, Kim SH, Lee SH, Cho TH, Sung CS. Combination therapy in treatment of sudden hearing loss. Korean J Otolaryngol 1995;38(8):1183-8.

5) Kido T, Sekitari T, Okinaka Y, Tahara T, Hara H. A case of cerebellar infarction occurred with 8th cranial nerve symptoms. Auris Narus Larynx 1994;21(2):11-7.

6) Hiroshi S, Masaru T, Shinji M, Masaaki S, Fumiyaki Y, Tomonori T. Sudden bilateral hearing loss and dizziness ocurred with cerebellar infarction. Otolaryngol Head and Neck Surg 2000;122(1):146-7.

7) Makins AE, Nikolopoulos TP. Is there a correlation between vascular loops and unilateral auditory symptoms? Laryngoscope 1998 Nov:1739-42.

8) Rubenstein RL, Norman DM, Schindler RA, Kaseff L. Cerebellar infarction: A presentation of vertigo. Laryngoscope 1980;90:505-14.

9) Marinkovic S, Kovaceric M, Gibo H, Milisavjevic M, Bumbasirevic L. The anatomical basis for cerebellar infarct. Surg Neurol 1995;44:450-61.

10) Chung WK, Eum JH, Hong HJ. A case of vertebrobasilar arterial insufficiency. Korean J Otolaryngol 1996;39:1519-26.

11) Henry JM, Barnett JP Mohr, Bennett M Stein, Frank M Yatsu. Vertebrobasilar occlusive disease. Stroke 3rd Ed. Churchill Livingstone company;1998. p.513-98. 